https://doi.org/10.18485/iipe_regbezb.2021.ch6

\title{
REGIONALNI BEZBEDNOSNI KOMPLEKS BLISKOG ISTOKA
}

\begin{abstract}
Stefan JOJIĆ1
Apstrakt: Sa akcentom na regionalnom nivou analize i ključnom uticaju regionalnih interakcija na bezbednosne ishode, teorija regionalnog bezbednosnog kompleksa (TRBK) pruža originalno polazište za izučavanje mnogih pitanja koja opterećuju savremenu međunarodno-političku zbilju. Kako bi izašla na kraj sa izazovima koje protok vremena i izuzetna dinamika međunarodne bezbednosti ispostavljaju pred TRBK, neophodno je izvršiti usklađivanje njenih teorijskih postavki i aparature prema impulsima iz empirije. Kao jedan od, $\mathrm{u}$ bezbednosnom smislu, najdinamičnijih regiona sveta izdvaja se Bliski istok, gde su ratovi, promene u raspodeli moći i specifični bezbednosni izazovi tokom protekle dve decenije uticali na promenu bezbednosne konfiguracije regiona. Konkretnije, dogodile su se manje ili veće promene u svim elementima esencijalne strukture regionalnog bezbednosnog kompleksa, čije detektovanje i objašnjenje predstavlja cilj ovog rada. Pojava novih i nestanak nekada ključnih činilaca regionalne bezbednosne dinamike, kao i prestrojavanje savezništava na bezbednosnoj slici Bliskog istoka, signaliziraju promene u obrazcima prijateljstava i neprijateljstava i raspodeli moći u regionu. Iako je većina starih obrazaca zadržana, dolazi do promene u pojedinim i stvaranja novih. Sa druge strane, i raspodela moći je narušena pojavom nedržavnih aktera, nestankom starih $\mathrm{i}$ jačanjem novih polova moći na bezbednosnoj mapi regiona. Neki od tradicionalnih obrazaca neprijateljstava, poput arapsko-izraelskog, potpali su u drugi plan, ustuknuvši pred pragmatičnom potrebom nekadašnjih neprijatelja za zajedničkim obuzdavanjem Irana. Raspodela moći je, takođe, izmenjena i aktivnim uključivanjem izolatora u regionalnu bezbednosnu dinamiku, gde
\end{abstract}

\footnotetext{
${ }^{1}$ Student doktorskih studija, Fakultet političkih nauka Univerziteta u Beogradu, Beograd.

E-mail: stefan.jojic@yahoo.com
} 
se Turska pojavljuje kao akter koji se tokom protekle decenije odlučujuće mešao u neka od gorućih pitanja regionalne konvencionalne i energetske bezbednosti. Specifična uloga Turske u Bliskoistočnom RBK nameće potrebu za preispitivanjem njene uloge insulatora/izolatora. Naposletku, kao posledica promena u prethodnim činiocima esencijalne strukture, došlo je do značajnih promena granica samog regionalnog bezbednosnog kompleksa. Specifična uloga koju Turska vrši proteklih godina dovela je do promene spoljnih granica njenim direktnim uključivanjem $u$ bezbednosnu dinamiku Bliskog istoka. Takođe, iako su i dalje prisutni faktori koji vezuju bezbednosnu dinamiku na širokom prostoru od Atlantika do Avganistana, držeći tako RBK Bliskog istoka na okupu, specifične podregionalne dinamike dovele su do promene unutrašnjih granica kompleksa, spajanjem i rekonfiguracijom potkompleksa.

Ključne reči: regionalni bezbednosni kompleks, Bliski istok, rat u Siriji, Turska, Iran.

\section{UVOD}

Niz protesta širom Bliskog istoka 2011. godine, poznatiji i kao „Arapsko proleće“ , u početku naizgled liberalnog karaktera, a potom ubrzo otuđenih od strane raznih ekstremističkih grupa, doveli su do urušavanja nekih od najznačajnijih država ovog prostora. Među državama koje su doživele najveću devastaciju je Sirija, gde je režim Bašara el Asada (Bashar al-Assad) na proteste odgovorio oštro, nakon čega su prodemokratski protestanti ubrzo ustuknuli pred radikalnim organizacijama koje su pokazale spremnost da učestvuju u eskalaciji nasija i prevođenju građanskog nezadovoljstva u oružani sukob. Dok je militarizacija sirijske revolucije od sredine 2011. godine imala presudnu ulogu u destabilizaciji regiona, akter čiji koreni leže u Iraku pojavio se kao značajan izazov njegovoj dugoročnoj stabilnost (Lister 2014, 4). Reč je o tzv. Islamskoj Državi (u daljem tekstu: ID) koja je na prostoru Sirije i Iraka nastojala da uspostavi državnu tvorevinu kao odskočnu dasku za krajnji cilj uspostave globalnog kalifata. Proces formiranja države je, ipak, pre bio karakterisan ekstremnim nasiljem nego izgradnjom institucija (Laub 2018). Pojava ID dala je povod za direktno mešanje nekih od regionalnih, ali i spoljnih sila, čemu je doprinosila i, često iznuđena, brutalnost Asadovog režima koja se u više navrata pojavila i kao direktan izgovor za intervenciju pojedinih država Zapada. Zapadne sile, pre svih Sjedinjene Američke Države (SAD) i 
pojedine evropske zemlje, u sukobima poput sirijskog videle su priliku za restruktuiranje regiona $\mathrm{u}$ skladu sa sopstvenim vrednosnim sistemom, odnosno zamenu problematičnih lidera. Asad svakako spada u jednog od njih, čija je nelojalnost, a ne stil vladavine, suštinski razlog koji se krije iza svrstavanja Sirije u grupu "otpadničkih država“, kojoj je presuđeno još u vreme američke invazije na Irak 2003. godine. Imperativ angažovanja imala je i Rusija, koja je sa Iranom najzaslužnija za Asadovu „pirovu pobedu“ u ratu sa najvećim brojem državnih i nedržavnih učesnika $u$ istoriji. Pored potrebe da sačuva saveznika i osigura svoje prisustvo u predelu istočnog Mediterana, Moskva je dominacijom na vojnom i diplomatskom poprištu sirijskog rata uspela da se, nakon dve decenije tavorenja, na velika vrata vrati na svetsku pozornicu (Janković 2020). Kao regionalni akter sa najkonkretnijim vojnim uplivom u tok rata, uz Iran, izdvaja se Turska, koja je, isprovocirana formiranjem kurdske autonomne oblasti na severu Sirije, u više navrata pokretala vojne operacije na ovom prostoru, što je za rezultat imalo da se značajni delovi severa zemlje i kurdskih etničkih prostora i dalje nalaze pod neposrednom kontrolom Ankare i njoj bliskih grupa.

Iako nije ni izbliza jedini bezbednosno interesantan događaj na Bliskom istoku u poslednjih dvadeset godina, sam rat u Siriji daje dovoljno povoda da se o regionalnoj bezbednosnoj dinamici na koju se fokusira teorija regionalnog bezbednosnog kompleksa (u daljem tekstu: TRBK) gleda iz drugačije perspektive. Ova teorija, koja naglašava značaj regionalnog nivoa analize $\mathrm{u}$ promišljanju bezbednosnih ishoda i postupaka država, nudi izgrađen aparat za razumevanje te dinamike, njenog porekla i interakcije sa susednim regionima. Regioni, odnosno, regionalni bezbednosni kompleksi (u daljem tekstu: RBK) određeni su elementima svoje esencijalne strukture koji pružaju jasne kriterijume za razumevanje njegovih svojstava i diferencijaciju u odnosu na druge RBK. Kompleksi su, kroz promene $u$ tim elementima, i sami podložni promenama, iako predstavljaju stabilne strukture. Ovo je naročito moguće usled značajnih promena u bezbednosnoj konfiguraciji pojedinih regiona, čemu su skloniji oni sa više polova moći i učestalim bezbednosnim izazovima, kakav je i Bliski istok. Cilj ovog rada je da utvrdi na koji su način značajna bezbednosna pitanja u prethodne dve decenije, poput rata u Siriji, uticala na esencijalnu strukturu Bliskoistočnog RBK, odnosno, elemente te esencijalne strukture - granice, raspodelu moći i obrasce prijateljstava i neprijateljstava. S obzirom na očigledno postojanje mnoštva samostalnih aktera, anarhija, četvrti element esencijalne strukture, neće biti posebno razmatran. 
Naredna poglavlja predstavljaju pokušaj da se, osvrtom na neke od najznačajnijih događaja i novih okolnosti, "ažurira“ bezbednosna slika regiona Bliskog istoka, koju su autori Kopenhaške škole predstavili pre skoro dvadeset godina. Prvo poglavlje daje pregled osnovnih teorijskih postavki TRBK, sa posebnim osvrtom na tada definisano mesto Bliskog istoka kao regiona u svetu regionalnih bezbednosnih kompleksa. Drugo poglavlje se bavi unutrašnjim promenama u bliskoistočnom RBK distribucijom moći, obrascima prijateljstava i neprijateljstava i promenama unutrašnjih granica kompleksa. Treće poglavlje bavi se spoljašnjim promenama kompleksa. Preciznije, ono razmatra novu ulogu Turske $u$ RBK, koja je kao aktivni izolator ${ }^{2}$ poslednjih godina sve više uključena $u$ regionalnu bezbednosnu dinamiku.

\section{TEORIJA REGIONALNOG BEZBEDNOSNOG KOMPLEKSA I MESTO BLISKOG ISTOKA U NJOJ}

Sa fokusom na regionalni nivo analize, TRBK nudi pristup razmatranja međunarodne bezbednosti decentralizovan od globalnog nivoa, koji je tokom perioda Hladnog rata imao mnogo veću ulogu $u$ definisanju bezbednosnih ishoda. Prestankom nadmetanja dve supersile, pale su i ideološke stege koje su, protezanjem širom svetskih regiona, nametale politiku u skladu sa dihotomijom "sa ili protiv nas“. Nove okolnosti su dovele do veće samostalnosti manjih sila, dajući više prostora njihovim sopstvenim interesima $u$ razmatranju za koju se od politika opredeliti $u$ odnosima prema svom susedstvu. Empirijske izazove su prepoznali teoretičari Kopenhaške škole, koji su kroz više radova postepeno zaokruživali TRBK (Buzan 1983; Buzan 1991), da bi ona definitivno bila uobličena $\mathrm{u}$ kapitalnom delu Regions and Powers: The Structure of International security iz 2003. godine (Buzan and Wæver 2003). Pored toga što predstavlja ishodiše njihovih teorijskih napora, svojim celovitim pristupom i fokusom na sve regione sveta, ova publikacija nudi pregled najvažnijih bezbednosnih pitanja za svaki od tih regiona.

TRBK predstavlja spoj neorealizma i konstruktivizma. Sa neorealizmom deli strukturalni pristup i fokus na raspodeli moći, s tom razlikom što logiku uravnoteživanja sa globalnog preslikava na regionalni nivo.

\footnotetext{
${ }^{2}$ Izolator, odnosno insulator jesu termini koji se, u smislu ove teorije, sinonimno koriste.
} 
Zajedničko sa konstruktivizmom TRBK ima u sekuritizaciji i načinu na koji se na nivou jedinica definišu pitanja koja će se naći na bezbednosnoj agendi. Regionalni bezbednosni kompleks autori definišu kao „set jedinica čiji su glavni procesi sekuritizacije, desekuritizacije ili oba, toliko povezani da se njihovi bezbednosni problemi ne mogu ispravno analizirati ili rešavati odvojeno jedni od drugih" (Buzan and Wæver 2003, 44). Anarhija, zajedno sa malom distancom, generiše regione, odnosno, klastere država gde je bezbednosna međuzavisnost znatno intenzivnija između članica samog klastera, nego što je to slučaj kada se radi o njihovim odnosima sa zemljama susednih regiona (Buzan and Wæver 2003, 46). U odsustvu regionalne integracije, dve ili više autonomnih jedinica, iliti država, zbog geografske bliskosti sklonije su da se suočavaju sa sličnim ili istim bezbednosnim izazovima. Naravno, mnogi od savremenih bezbednosnih izazova su globalne prirode i deli ih najveći broj država, ali oni tradicionalni oblici se i dalje najintenzivnije ispoljavaju na regionalnom nivou - poput prelivanja lokalnih ratova, rivalstava manjih sila sa regionalnim domašajem ili suočavanja država sa nekim od pretnji regionalnog karaktera. Države izolatori, locirane na obodima snažnih obrazaca sekuritizacije, razdvajaju bezbednosne dinamike susednih regiona (Buzan and Wæver 2003, 41). Izolatori su na izvestan način i sami uključeni u bezbednosne dinamike svoga okruženja, ali sa znatno manjim intenzitetom i nikako kao jedan od centralnih subjekata regionalne sekuritizacije. Ujedno, oni predstavljaju branu prelivanja bezbednosnih izazova iz jednog regiona $u$ drugi.

U zavisnosti od prirode odnosa između članica, pravi se razlika između standardnih i centriranih RBK (Buzan and Wæver 2003, 55). Standardni RBK je sastavljen od dva ili više aktera, čijom bezbednosnom agendom dominiraju klasična vojno-politička pitanja. Bliski istok je tipičan primer multipolarnog standardnog RBK. Centrirani, s druge strane, podrazumeva izvorište bezbednosne međuzavisnosti u postojanju izrazito dominantne sile, kakav bi bio Postsovjetski RBK okupljen oko Rusije, ili u postojanju institucionalne integracije koja drži članice na okupu, kakva je Evropska unija. Alternativa postojanju RBK u određenim regionima su situacije gde on još uvek nije formiran usled nepostojanja bezbednosne međuzavisnosti između susednih država i društava, ili situacije gde su, zbog protezanja uticaja neke velike spoljne sile, regionalne bezbednosne dinamike skrajnute u drugi plan ili praktično ukinute, kakva je bila situacija sa prostorima kolonizovanim od strane evropskih država. 
Esencijalna struktura je ono što regionalnom bezbednosnom kompleksu daje osobenost. Anarhija je prvi element esencijalne strukture i podrazumeva postojanje dve ili više autonomnih jedinica u RBK (Buzan and Wæver 2003, 53). Granice su ono što razdvaja jedan kompleks od drugog i izolatori se, ukoliko postoje, nalaze upravo na tim linijama razgraničenja dva regiona. Kompleksi imaju i unutrašnje granice koje razdvajaju potkomplekse, odnosno delove RBK sa nekom sebi svojstvenom bezbednosnom dinamikom, ili one prostore na kojima je regionalna bezbednosna dinamika različitog intenziteta u odnosu na druge delove kompleksa. Treći element esencijalne strukture je polaritet koji govori o raspodeli moći između jedinica kompleksa (Buzan and Wæver 2003, 53). Poslednji element je vezan za socijalnu konstrukciju i obrasce prijateljstava i neprijateljstava koji definišu bezbednosnu dinamiku, a samim tim i regionalne bezbednosne komplekse.

Promene u elementima esencijalne strukture dovode do transformacije RBK (Buzan and Wæver 2003, 53). Unutrašnja transformacija podrazumeva promene u okviru postojećih spoljnih granica kompleksa. Promena anarhične strukture, usled regionalne integracije, mogla bi da bude jedna vrsta unutrašnje transformacije. Promena polariteta je čest oblik unutrašnje transformacije RBK, s obzirom na to da su dezintegracija država, njihovo spajanje ili rapidno jačanje uobičajene pojave u međunarodnim odnosima. Takođe, promene $u$ obrascima sekuritizacije su jedan od čestih oblika unutrašnje transformacije, budući da je nekada samo promena vlasti $u$ jednoj državi dovoljna da izmeni način na koji ona percipira okruženje, i obratno. Kao unutrašnja transformacija RBK može se uzeti i promena njenih unutrašnjih granica, promenom članstva u potkompleksima, njihovim nestankom ili stvaranjem novih. Spoljašnja transformacija RBK podrazumeva promenu njenih spoljnih granica, promenom članstva $u$ kompleksu, raspadom kompleksa ili njegovim spajanjem sa drugim RBK (Buzan and Wæver 2003, 53). Spoljašnja transformacija, sasvim izvesno, podrazumeva promene i u drugim elementima esencijalne strukture.

\section{Bliski istok u svetu regionalnih bezbednosnih kompleksa}

Dominantni obrasci sekuritizacije na Bliskom istoku, raširena neprijateljstva i rivalstva, i odsustvo regionalnih bezbednosnih organizacija i režima, čine da regionalna bezbednosna konstelacija odgovara konfliktnoj formaciji. Radi se o regionu gde su „obrasci bezbednosne međuzavisnosti oblikovani strahom od rata i očekivane upotrebe nasilja u političkim 
odnosima" (Buzan and Wæver 2003, 489). Bliskoistočna konfliktna formacija vođena je tradicionalnom agendom teritorijalnih sporova, ideološkim nadmetanjem, rivalstvima oko moći i statusa i etničkim i kulturnim podelama (Buzan and Wæver 2003, 193-194). Uprkos kulturnoj, društvenoj i verskoj sličnosti i postojanju pregršt regionalnih organizacija, debata o statusu Bliskog istoka se često svodi na ocene da se radi o "regionu bez regionalizma“ (Aarts 1999; Santini 2017). Upravo suprotno regionalizaciji, region Bliskog istoka se od procesa dekolonizacije nalazi u nekoj vrsti permanentnog regionalnog hladnog rata, ali sa državama regiona kao glavnim akterima, kada su popustile stege koje je nametnulo nadmetanje supersila.

Bliskoistočni RBK prostire se od Atlantika na zapadu Severne Afrike do Irana na istoku, i sastoji se od tri potkompleksa - zalivskog, levantskog i potkompleksa Magreba (Karta 1). Ono što je omogućilo povezivanje bezbednosnih dinamika na tako velikom prostoru jesu postojanje arabizma i islama, kao zajedničkih karakteristika najvećeg broja država, i fokus na konflikt sa Izraelom (Buzan and Wæver 2003, 191).

Karta 1: Prikaz regionalnog bezbednosnog kompleksa Bliskog istoka iz 2003. godine

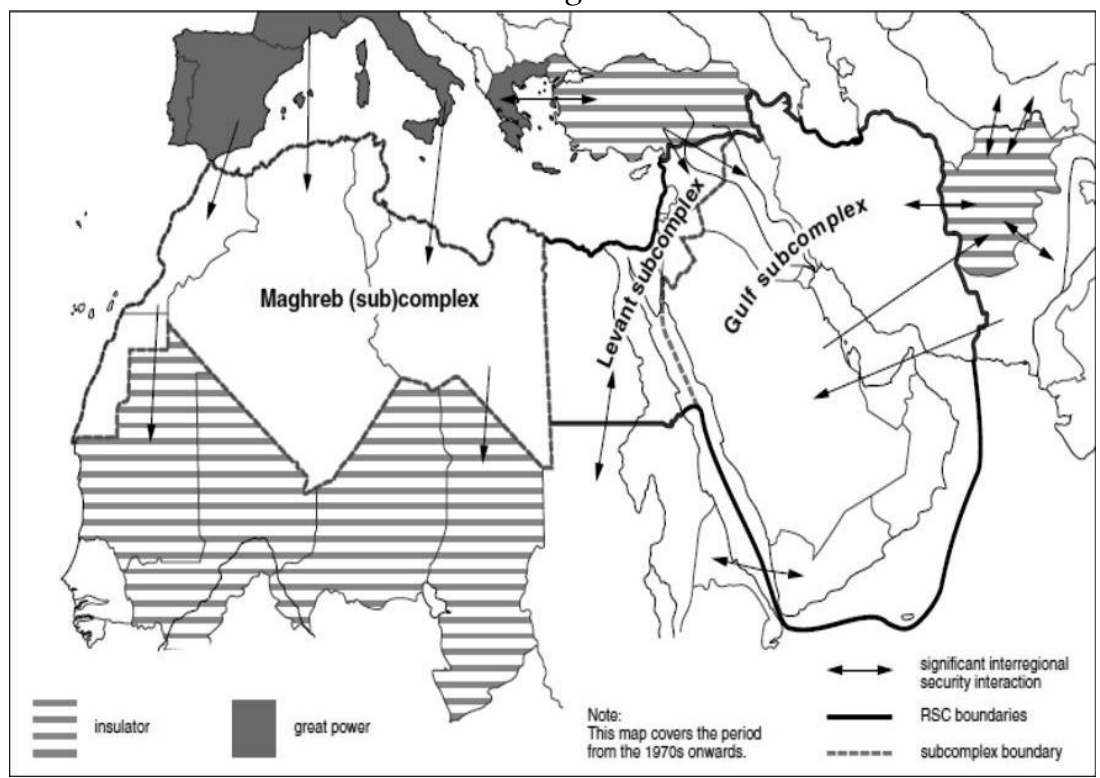

Izvor: Buzan and Wæver 2003, 189. 
Budući da se na prostoru od Maroka do Iraka nalaze države nastanjenje arapskom populacijom, $\mathrm{u}$ periodu nakon dekolonizacije došlo je do nadmetanja država za primat $\mathrm{u}$ arapskom svetu. Nekada živa ideologija pan-arabizma ili pan-arapskog nacionalizma, značila je borbu između tada najmoćnijih arapskih država za mesto pijemonta arapskog nacionalnog okupljanja, odnosno otpor takvom poduhvatu od strane pojedinih država koje tu ideologiju nisu delile sa Naserovim Egiptom ili sekularnom i socijalističkom Baas partijom. Bez etničkih i lingvističkih sličnosti, sama interakcija, a samim tim i bezbednosna međuzavisnost između Egipta i Iraka, bila bi znatno nižeg intenziteta. Arabizam tako predstavlja trajni vezivni element na širokom prostoru Magreba i Mašreka.

Činjenica da se, sem Izraela, radi o dominantno muslimanskim zemljama, drugi je vezivni element Bliskoistočnog RBK. To je često značilo da se despotski vladari širom Bliskog istoka suočavaju sa istim izazovima za očuvanje sopstvene vlasti. Islamistički politički pokreti su se decenijama nametali kao alternativa kako sekularnim, socijalističkim vlastodršcima, tako i monarsima koji su se oslanjali na podršku Zapada. Iako se ne radi o arapskoj zemlji, upravo je jedan takav pokret doveo do kraja vladavina šaha u Iranu 1979. godine. Od tada, zbog svoje podrške "islamskom buđenju“ širom Bliskog istoka, Iran se od strane mnogih država percipira kao pretnja regionalnom statusu quo. Među islamskim pokretima se svakako izdvaja Muslimansko bratstvo, od čijeg političkog delovanja podjednako zaziru u Kairu i Rijadu. Veliki broj pokreta se opredelio i za nasilne metode političke borbe, pa transnacionalni islamski terorizam ili mogućnost oružane pobune od strane istih predstavlja jedan od izazova sa kojim se suočavaju zemlje Bliskoistočnog RBK.

Fokus na izraelsko-palestinskom sukobu je jedan od nosećih stubova bezbednosne dinamike Bliskog istoka. Ovaj sukob je često bio centralna tema sastanaka regionalnih arapskih i islamskih organizacija, poput Arapske lige ili Organizacije islamske saradnje. On se nalazi i kao izvorište unutrašnjeg legitimiteta u pojedinim državama, kao što je slučaj sa politizacijom izraelsko-palestinskog sukoba u Iranu. Fokus na borbu za prevlast $u$ "Svetoj zemlji“ podrazumevao je trajnu angažovanost arapskih država i Irana od 1979. godine, bilo da se radi o političkoj podršci bilo o pružanju materijalne potpore vojno-političkim organizacijama koje se bore sa Izraelcima - Palestinskoj oslobodilačkoj organizaciji, Hamasu i Hezbolahu (Buzan and Wæver 2003, 190-193). Takođe, antiizraelski motivi 
su se našli kao direktan povod za nekoliko arapsko-izraelskih ratova, često vođenih od strane koalicije arapskih država.

Bez ova tri vezivna elementa, verovatno ne bi bilo ni Bliskoistočnog RBK, već bi udaljenost država jednih od drugih diktirala postojanje dva ili tri manja kompleksa, formirana oko Persijskog zaliva, Levanta i Magreba (Buzan and Wæver 2003, 191). Pored deljenja tri zajednička elementa sa ostalim, Zalivski potkompleks ima i specifičnu unutrašnju bezbednosnu dinamiku, formiranu kao rezultat nadmetanja tri najveće države Persijskog zaliva - Saudijske Arabije, Iraka i Irana. Postojanje Levantskog potkompleksa diktira geografska blizina Izraelu i znatno veća fokusiranost okolnih država na izraelsko-palestinski sukob. Geografija, odnosno udaljenost od specifičnih unutrašnjih bezbednosnih dinamika druga dva potkompleksa, glavni je razlog zbog koga je i Magreb prepoznat kao poseban potkomleks.

Avganistan je jedna od država koju su autori prepoznali kao izolatora, dodeljujući mu ulogu razgraničenja između Bliskoistočnog i regionalnog bezbednosnog kompleksa Južne Azije. Mnogo značajniju ulogu Buzan i Vejver su dodelili Turskoj, koja razdvaja Bliskoistočni od Evropskog i Postsovjetskog RBK. Prema njima, turska sposobnost da izoluje jedne od drugih bezbednosnih dinamika je dodatno pojačana njenom prozapadnom orijentacijom koju je utemeljio Ataturk, čime je okrenula leđa svojoj prošlosti i znatno smanjila nivo političkog angažovanja u svom susedstvu (Buzan and Wæver 2003, 187). S obzirom na to da je u trenucima pisanja ove knjige Turska već uveliko radila na širenju svog uticaja širom svog okruženja, autorski dvojac joj je dodelio ulogu aktivnog izolatora.

\section{UNUTRAŠNJE PROMENE U REGIONALNOM BEZBEDNOSNOM KOMPLEKSU BLISKOG ISTOKA}

\section{Raspodela moći}

Promene $\mathrm{u}$ raspodeli moći $\mathrm{u}$ Bliskoistočnom RBK odvijale su se dvosmerno - kako gubitkom materijalnih sposobnosti od strane pojedinih država, tako i akumulacijom tih kapaciteta. Najznačajniji događaj za prvi proces svakako predstavlja "Arapsko proleće" i čitav niz građanskih ratova $\mathrm{u}$ koje su pojedine države Bliskog istoka utonule ubrzo po eskalaciji nasilja na protestima. Kao rezultat, Jemen i Libija danas praktično ne postoje kao 
države. Jemen se od kraja 2014. godine nalazi u građanskom ratu između nekoliko frakcija, potpomognutih od strane zainteresovanih spoljnih aktera. Uprkos rasprostranjenosti oružanih formacija širom zemlje, razorena zemlja, koja je već godinama suočena sa humanitarnom katastrofom, suštinski ne postoji kao politički subjekat i teško da se može uzeti kao značajan akter u Zalivskom potkompleksu. Situacija je slična i u Libiji, gde se za prevlast bore grupacije koje sebe vide kao legitimnog predstavnika zemlje u međunarodnim odnosima. Međutim, posledice proistekle po raspodeli moći u Bliskoistočnom RBK su daleko veće u slučaju Libije, budući da je ona bila značajan akter potkompleksa Magreba i država sa znatno većim političkim uticajem na Bliskom istoku. Sličnu sudbinu bi doživela i Sirija da predsednik Asad, uz pomoć Rusije i Irana, nije uspeo da povrati kontrolu nad najvećim delom zemlje. Zemlja je, ipak, razorena i trebaće joj decenije da povrati politički uticaj i vojnu moć koju je imala pre izbijanja sukoba. Ona to neće moći da postigne bez znatne podrške međunarodnog faktora, što joj samo po sebi ne garantuje uspeh, tim pre što će na putu ka obnovi celovitosti morati da sklapa kompromise koji će umanjiti unutrašnju političku moć centralne vlasti u Damasku. Takođe, od perioda kada su autori Kopenhaške škole formulisali RBK Bliskog istoka, značajne promene u moći pretrpeo je i Irak. Samom invazijom koalicije predvođene Sjedinjenim Državama 2003. godine, Irak je skliznuo na poziciju drugorazredne sile u Persijskom zalivu, prepustivši Iranu i Saudijskoj Arabiji pozicije "motora" regionalne bezbednosne dinamike Zalivskog potkompleksa. Irak je, zapravo, utonuo u deceniju unutrašnjih nestabilnosti, gde su razne etničke i verske grupe nastojale da ostvare svoje međusobno suprotstavljene interese (Saouli 2016, 93). Rat sa Islamskom državom od 2011. godine samo je udaljio nekada moćnu zalivsku zemlju od mogućnosti da u budućnosti ponovo postane relevantan igrač na bezbednosnoj mapi Bliskog istoka.

Od prelaska Iraka sa značajnog relevantnog subjekta regionalne politike na status objekta i poprišta borbe za moć drugih zemalja, najveću neposrednu političku korist ostvario je Iran. Preuzimanjem moći u zemlji od strane šiita Iran je, pored Sirije i Hezbolaha, potencijalno dobio još jednu kariku u svojoj osovini otpora Izraelu i zapadnom imperijalizmu. Ovo je dočekano sa negodovanjem $\mathrm{u}$ arapskim monarhijama koje su u novim okolnostima videle samo jedan $\mathrm{u}$ nizu postupaka koji signaliziraju jasnu iransku ekspanziju u regionu. Povod za zabrinutost monarhija iz Persijskog zaliva svakako predstavlja i iranska vojna sila, čija su tri stuba sajber 
sposobnosti, pomorske snage i balistički projektili (Bahgat and Ehteshami 2017, 90). Iranska vojska je naročito prepoznatljiva po velikom broju balističkih projektila u svom posedu, koje su rezultat ulaganja u domaću odbrambenu industriju. Čak i kada su naoružani konvencionalnim bojevim glavama, projektili imaju moć da nanesu nesagledivu štetu njihovim rivalima sa druge strane Zaliva. Mogućnosti za agresiju ili odmazdu Irana su utoliko veće što su iranskim projektilima kratkog i srednjeg dometa naoružani njihovi ne-državni saveznici i grupe koje materijalno pomažu, poput Hamasa, Hezbolaha ili Huta u Jemenu. Kao najvažnije ograničenje za dalji rast iranske vojne sile i uvoz sofisticirane opreme, mora se uzeti impotentnost njihove ekonomije usled ekonomskih sankcija sa Zapada kojima su godinama izloženi.

Vojna sila Saudijske Arabije izgrađena je na sasvim drugačiji način. Za razliku od Irana, Rijad itekako ima finansijskih sredstava za nabavku naoružanja iz inostranstva - ukupan uvoz oružja Irana za period od 20092018. godine predstavlja tek 3,5\% onoga što je Saudijska Arabija uvezla za isti period (Wezeman and Kuimova 2019, 2). Prema podacima Stokholmskog međunarodnog instituta za istraživanje mira, Saudijska Arabija se poslednjih godina nalazi u samom vrhu zemalja po izdvajanjima za odbranu, bilo da se radi o apsolutnim novčanim iznosima ili opterećenju bruto domaćeg proizvoda tim izdacima (SIPRI 2020). Kao rezultat ulaganja petrodolara u odbranu, Saudijska Arabija je danas među najjačim vojnim silama na Bliskom istoku. Verovatno najveću pažnju privuklo je nedavno sklapanje sporazuma o nabavci naoružanja sa SAD, čemu je kumovalo insistiranje tadašnjeg američkog predsednika Trampa da saveznici moraju da snose deo opterećenja za bezbednosni kišobran koji im pruža Amerika (Jojić 2019). Na putu akumulacije vojnih sposobnosti, Saudijsku Arabiju u stopu prate manje saveznice iz Saveta za saradnju zemalja Persijskog zaliva (Wezeman 2011; Wezeman and Kuimova 2019), koje sa Rijadom dele veliki broj bezbednosnih izazova i interesa u regionu, i koje su i same $u$ vrhu liste zemalja sveta po izdacima za odbranu.

Vojne sile Izraela i Egipta predstavljaju priču o stagnaciji kada se radi o periodu od poslednjih dvadeset godina, međutim, sa potpuno različitih polaznih osnova. Uprkos svojoj veličini i primatu koji je nekada imala, egipatska vojska se nikada nije oporavila od poraza od Izraela u Šestodnevnom ratu 1967. godine i nekoliko ratova koji su usledili. Ratno vazduhoplovstvo nekada najmoćnije arapske države tada je gotovo $u$ potpunosti uništeno, a ekonomske neprilike nisu dozovoljavale Egiptu da 
povrati status koji je imao pre serije poraza koje je pretrpeo od Izraela. Sa druge strane, Izrael je i dalje prvorazredna vojna sila na Bliskom istoku, sa najsofisticiranijom vojnom opremom i najrazvijenijom odbrambenom industrijom. Upravo je domaća industrija ono što daje kvalitativnu prednost izraelskoj vojci u odnosu na svoje arapske susede i Iran (HassanYari 2016, 103-104). Pored mogućnosti za izvoz i zaradu, izraelska vojna industrija je garant da će jevrejska država i u budućnosti biti jedan od glavnih činilaca regionalne bezbednosne dinamike.

Izrael je i jedina nuklearna sila na Bliskom istoku, iako to nikada zvanično nije potvrđeno. Procene $u$ broju izraelskog nuklearnog oružja se kreću u rasponu od 60 pa čak do 400 nuklearnih bojevih glava (Fitzpatrick 2011, 3). Postojanje ,jevrejske bombe“ silno je motivisalo islamske države iz regiona da posegnu za nekim od primeraka nekonvencionalnog strateškog naoružanja. Najdalje je u tom pravcu otišao Iran, koji je tokom prve decenije XXI veka ostvario izuzetan napredak na polju obogaćivanja uranijuma (Rezaei 2017, 82). Program obogaćivanja uranijuma, koji je vremenom postao simbol suvereniteta i prkosa Irana Zapadu, Teheran je 2015. godine istrgovao za delimično ukidanje sankcija od strane zapadnih država. Međutim, nakon jednostranog napuštanja sporazuma od strane SAD, Iran je nastavio sa obogaćivanjem uranijuma preko granice dogovorene Zajedničkim sveobuhvatnim akcionim planom, poznatijim kao „Iranski nuklearni sporazum". Izrael i Saudijska Arabija su zemlje koje najviše negoduju zbog iranskog nuklearnog programa i sasvim je sigurno da neće nemo posmatrati kako njihov arhineprijatelj pribavlja najrazornije oružje. Izostanak trajnog rešenja ovog problema sa sobom nosi potencijal za dalju destabilizaciju regiona, bilo da se radi o mogućnosti preventivnog udara neke od zabrinutih država, bilo o daljoj proliferaciji nuklearnog naoružanja.

\section{Obrasci prijateljstava i neprijateljstava}

Zategnuti odnosi Saudijske Arabije i Irana predstavljaju jedan od najtrajnijih i najvažnijih obrazaca neprijateljstva koji je profilisao bezbednosnu dinamiku Zalivskog potkompleksa, ali i Bliskoistočnog RBK u celini. Sukob dve najveće države Persijskog zaliva svoje izvorište ima najpre u identiteskim razlikama, budući da su sukobi Persijanaca i Arapa za prevlast nad Zalivom stariji od najvećeg broja država tog prostora. Identitetske nesuglasice se mogu sagledati i u verskim razlikama jer je Iran najveća šiitska zemlja, dok je Saudijska Arabija većinski sunitska zemlja, u 
kojoj se nalaze Meka i Medina, dva najsvetija grada za islam. Kasnije, nakon Islamske revolucije u Iranu 1979. godine, sukob je dobio i ideološku dimenziju, s obzirom na isključivost vahabizma prema drugim islamskim učenjima i tadašnju težnju Rijada da svoj verski pravac izveze širom islamskog sveta. Insistiranje na verskom puritanizmu i podsticanje islamskog buđenja širom Bliskog istoka od srane Teherana su, pored pojačanog nadmetanja dve strane, doveli u pitanje i usklađenost politike kuće Sauda sa islamskim idealima koje propagiraju (Axworthy 2017, 24). Pored identitetsko-ideološke komponente, saudijsko-iranski sukob imao je podsticaj i u geopolitičkim okolnostima. Sa jedne strane, Iran je u Rijadu video produženu ruku SAD, svog dojučerašnjeg saveznika, a nakon revolucije 1979. godine svog najvećeg spoljnopolitičkog protivnika. Sa druge, Saudijska Arabija, ali i pojedine države Zaliva, imaju značajan deo šiitske populacije $i$ to baš na onim delovima teritorije koji su bogati energentima - oko polovine njihovih naftnih rezervi nalazi se u regionima sa šiitskom većinom (Oktav 2011, 138). Ove okolnosti su same po sebi upućivale na strah da bi ta populacija mogla da bude instrumentalizovana od zemlje koja se percipira kao lider šiitskog sveta.

Nedugo nakon neuspelih pokušaja da se odnosi dve zemlje poprave $u$ vreme mandata iranskih predsednika Rafsanžanija (Akbar Hashemi Rafsanjani) i Hatamija (Mohammad Khatami), po svrgavanju Sadama Huseina odnosi Saudijske Arabije i Irana su krenuli silaznom putanjom. S obzirom na rasplet iračke krize koji je išao na ruku Teheranu, Iran se od strane arapskih monarha ubrzo našao optužen za stvaranje „,̌iitskog polumeseca“ - prostora od Avganistana do Mediterana pod dominacijom Teherana (Wright and Beker 2004). Po izbijanju "Arapskog proleća“ odnosi se dodatno zaoštravaju, budući da je u očima arapskih vlastodržaca Iran prepoznat kao potencijalno najveći dobitnik smena vlasti koje su potresale prostor Bliskog istoka. I jedna i druga strana su podržavale samo one revolucije koje su išle na ruku njihovim političkim interesima. Na primer, Iranci su u padu Mubaraka u Egiptu videli „islamsko buđenje“, dok su na islamističku alternativu koja se nametala socijalisti Asadu gledali kao podvalu zapadnog imperijalizma. Slična analogija se preslikava i na način na koji su u Rijadu gledali na revolucije u ove dve zemlje. Usledila je borba za suzbijanje uticaja druge strane i čitav niz ratova preko zastupnika (proxy wars). Nakon što su "kupili“ socijalni mir na svojoj teritoriji, Saudijci su 2011. godine vojno intervenisali u Bahreinu, zalivskoj državi gde je većinsko šiitsko stanovništvo pretilo da zbaci vladajući sunitski režim (Mabon 2012, 89). U 
Siriji su Saudijci podržavali grupe suprotstavljene Asadu, sa primarnim ciljem da se suzbije uticaj Hezbolaha i Irana. Slične motive imali su i za uključenje u jemenski građanski rat, s obzirom na to da je šiitski Huti pokret viđen kao potencijalni proksi Irana, ali ovoga puta u saudijskom dvorištu.

Celokupno nadmetanje dve zemlje zasniva se na principima „igre sa zbirom $0^{\mu \prime}$, gde se dobici za jednu stranu opažaju kao gubici za drugu. Neretko, nadmetanje je prevazilazilo ratovanje preko zastupnika, imajući $\mathrm{u}$ vidu da se iranska nuklearna i postrojenja saudijske naftne kompanije Aramko često nalaze na udaru sajber napada (Sullivan 2016, 74). Pored proksi sukoba i korišćenja savremenih metoda ratovanja, mogućnost eskalacije oružanih sukoba dve strane ostaje opasnost po bezbednost čitavog prostora Persijskog zaliva. Saudijci su svojevremeno zagovarali preventivne udare na iranska nuklearna postrojenja, kako bi se jednom za svagda stavila tačka na njihovu mogućnost da jednom naprave bombu. Iranci, s druge strane, često prete upotrebom svojih projektila protiv arapskog suseda, kao što je bio slučaj pretnje iranskog visokog zvaničnika da će, u slučaju potrebe za odmazdom, Meka i Medina ostati jedini neporušeni gradovi na teritoriji Saudijske Arabije (Tasnim News Agency 2017). Navedeni primeri govore o meri u kojoj su dva aktera sekuritizovala jedan drugog kao pretnje sopstvenom opstanku. Ukoliko bi retorika kojom se služe dve strane bila pretočena u konkretne postupke, usledila bi razaranja velikih razmera, što čitavom sukobu daje težinu u procesu definisanja regionalne bezbednosne dinamike.

Drugi značajan i trajan obrazac sekuritizacije predstavlja neprijateljstvo Izraela i okolnih muslimanskih zemalja, odnosno neprijateljstvo Izraelaca i Palestinaca u prvom redu. Dokle god izostaje konačno rešenje ovog sukoba, sasvim je izvesno da će dve strane jedna drugu opažati kao pretnje sopstvenom ostanku. Bez postizanja apsolutne prevlasti jedne od strana ili pak trajnog razgraničenja, delovanje Izraela, s jedne, i palesinskih političkih organizacija poput Hamasa ili umerenijeg Fataha, s druge strane, biće jedan od ključnih faktora nestabilnosti na Bliskom istoku. U ovu računicu treba uzeti i Hezbolah koji, pored nadmetanja za moć u Libanu, za jedan od spoljnopolitičkih prioriteta ima oponiranje cionizmu.

Neprijateljstvo između Izraela i okolnih arapskih zemalja, kako ono očigledno u diskursu koje strane neguju o drugoj tako i ono koje se može sagledati iz konkretnih političkih ishoda, znatno je oslabilo u poslednjih dvadeset godina, a naročito u poređenju sa onim iz perioda Hladnog rata kada je samo postojanje Izraela posmatrano kao prvorazredni bezbednosni 
problem za okolni islamski svet. Deo razloga $\mathrm{u}$ tome zasigurno se krije $\mathrm{u}$ činjenici da je relativna moć Izraela spram svog neposrednog okruženja znatno uvećana, kao rezultat ulaganja u sopstvene kapacitete, ali i kao posledica slabljenja tradicionalnih neprijatelja. Sirija zadugo neće moći da $\mathrm{u}$ ozbiljno razmatranje uzme težnju da povrati okupiranu Golansku visoravan, a još manje da sopstvenim zalaganjem doprinese rešavanju sukoba u korist palestinske braće. Egipat je daleko slabija država u odnosu na period kada je bio perjanica antiizraelske koalicije na Bliskom istoku. Dodatno, Kairo je danas više zabrinut za svoju unutrašnju stabilnost $i$, posledično, više je zagledan u svoju zapadnu granicu nego liniju koja razdvaja Izrael od Sinajskog poluostrva. Nakon nekoliko izgubljenih ratova od Izraela, koji su za rezultat imali i sve veću marginalizaciju palestinskog političkog faktora na tom prostoru, impulsi za ozbiljniju vojnu ili političku intervenciju okruženja su splasnuli. Sa nesmanjenim rizikom u odnosu na prethodne intervencije, danas je maksimum koji se može izvući iz združene antiizraelske akcije daleko niži nego što je to bio slučaj do Izraelske okupacije i naseljavanja Zapadne obale jevrejskom populacijom. Naravno, svako rasplamsavanje sukoba između izraelskih snaga i neke propalestinske vojno-političke organizacije nosi sa sobom rizik od zaoštravanja odnosa sa susednim arapskim državama. Međutim, zaoštravanje, kao po pravilu, ostaje na retorici a levantske države, do juče najveći zagovornici palestinskih prava, nisu ni izbliza među najagresivnijim u svojoj reakciji.

I monarhije iz Persijskog zaliva su sve manje raspoložene za agresivnu reakciju u slučaju eskalacije nasilja u Palestini, a još manje za agresivno obuzdavanje Izraela u periodima kada oružana borba u svetoj zemlji izostaje. Nekada značajni sponzori palestinske borbe protiv okupacije, poslednjih godina su značajno ublažili retoriku kada se radi o izraelskopalestinskom sukobu. Štaviše, Saudijska Arabija je na sastancima Arapske lige svojevremeno zagovarala postizanje mirnog rešenja ovog sukoba (Blanga 2017, 45). Razlog zagovaranja konačnog rešenja od strane Rijada može se naći u tome što trenutna situacija najviše pogoduje Iranu. Postojanje izralesko-palestinskog konflikta i povremena eskalacija nasilja pruža Iranu podlogu za legitimizaciju svog prisustva širom Bliskog istoka $\mathrm{i}$ isticanje negativne uloge SAD na Bliskom istoku. Takve okolnosti na izvestan način delegitimišu i uticaj Saudijske Arabije pred arapskom javnošću, s obzirom na njenu pasivnost i oslonac na aktere sa Zapada. Istovremeno, nerešavanje sukoba otvara prostor za dalje prisustvo Irana na Levantu preko svojih proksija - Hamasa i Hezbolaha. 
Razlog za otopljavanje odnosa zalivskih monarhija i Izraela, koje datira u proteklih nekoliko godina, može se naći u njihovom zaoštravanju odnosa sa Iranom. Iran danas daleko više ugrožava bezbednost i interese Saudijske Arabije nego što je to slučaj sa Izraelom. Otuda i ne čudi što se sve češće govori o stvaranju koalicije Izraela i članica Saveta za saradnju zemalja Persijskog zaliva, s ciljem obuzdavanja sve agresivnije iranske regionalne politike (Beck 2019; Beck 2020). Intenziviranje spekulacija o stvaranju antiiranske osovine na Bliskom istoku poklapa se sa mandatom američkog predsednika Donalda Trampa, koji je, za razliku od svog prethodnika Obame, spoljnu politiku na Bliskom istoku rasteretio insistiranja na poštovanju ljudskih prava, što je dovelo do popravljanja odnosa sa Izraelom i Saudijskom Arabijom. Napuštanjem Obamine politike zbližavanja sa Iranom, odnosno njenim potpunim izokretanjem u politiku obuzdavanja, stvoreni su uslovi za približavanje dojučerašnjih neprijatelja. Tokom 2020. godine došlo je do potpisivanja sporazuma o normalizaciji odnosa Izraela i Ujedinjenih Arapskih Emirata (Alsaafin 2020), što bi moglo da predstavlja prvi korak $u$ široj normalizaciji odnosa Izraela i arapskih država, pre svih Saudijske Arabije. U novembru iste godine, svetski mediji su preneli informaciju o tajnoj poseti izraelskog premijera Rijadu, gde se navodno sastao sa saudijskim prestolonaslednikom (Holmes 2020), što su Saudijci demantovali. Podsticaji za približavanje postoje, a u ovom trenutku kao prepreka punoj normalizaciji odnosa ostaje nerešen izrealsko-palestinski sukob, čije će rasplamsavanje u maju 2021. godine svakako privremeno zaustaviti taj proces. Ipak, eskalacija nasilja u pojasu Gaze teško da će trajno narušiti odnose dve strane, smrtno zabrinute zbog pretnje koja stiže iz Teherana.

Od svih muslimanskih zemalja Bliskog istoka, Iran je ostao najdosledniji i najčvršći u svom anticionizmu, bilo da se radi o retorici ili konkretnim postupcima na terenu. Nema sumnje da dve države jedna drugu vide kao pretnje sopstvenom opstanku. Dok Izraelci sprovode sajber napade na iranska nuklearna postrojenja, preteći čak i strateškim napadom, uništenje Izraela je često pominjana tema $u$ visokoj politici persijske države (Taha 2021). Uprkos velikoj udaljenosti, dve strane imaju kapaciteta da naude jedna drugoj (Wezeman 2011, 4-7) pa se obostrane pretnje ne mogu uzeti kao puko retoričko dizanje očekivanja domaće i međunarodne javnosti. Kroz ovu prizmu treba gledati i zabrinutost Izraela zbog prisustva Irana na Mediteranu i njihove podrške Hezbolahu. Angažovanje Irana i Hezbolaha u sirijskom građanskom ratu za cilj ima očuvanje Asada na 
vlasti, $\mathrm{i}$ tako kontinentalne veze između njih i bitne karike u osovini otpora izraelskoj i američkoj dominaciji na Bliskom istoku (Kizilkaya 2017, 211222). Sa druge strane, povremeni napadi Izraela na Siriju tokom poslednjih deset godina su upravo izvedeni na način da nanose gubitke Iranu, Hezbolahu i njihovom savezniku Asadu, bez koga teško da bi bilo i njihovog prisustva na terenu.

Za razliku od promena koje su se dogodile $u$ prethodna dva obrasca, zaziranje bliskoistočnih despotskih režima od političkog islama pokazalo se kao trajan obrazac sekuritizacije RBK Bliskog istoka, a celom procesu je dosta doprinelo poistovećivanje sopstvenog opstanka na vlasti sa bezbednošću države. Tako sa "Arapskim prolećem“ dolazi do promene diskursa o spoljnoj pretnji bezbednosti države ka većem naglašavanju lokalnih i regionalnih pretnji (Koch 2019, 6-7). Ako su se tokom Hladnog rata Egipat i Saudijska Arabija složili da je Izrael njihova velika regionalna pretnja, danas je to slučaj sa Muslimanskim bratstvom. Kao rezultat, ubrzo je formirana koalicija aktera različitih ideoloških profila, ali sa zajedničkim interesima. Dok su u Egiptu sekularni vojni krugovi zbacili islamističkog predsednika Morsija, koalicija okupljena oko Saudijske Arabije radila je na suzbijanju uticaja Muslimanskog bratstva u Zalivu, dovodeći u pitanje odnose sa nekim od tradicionalnih saveznika, poput Katara. Islamisti su se pojavili kao najozbiljnija alternativa vlasti i u drugim revolucijama "Arapskog proleća“, ali primer Muslimanskog bratstva sam po sebi dovoljno govori $u$ prilog tezi o univerzalnosti jednog od obrazaca neprijateljstava na Bliskom istoku. $\mathrm{Na}$ izvestan način, sekuritizacija islamističke opozicije od strane vladara Bliskog istoka, nakon 2011. godine, pokazala je da na širokom prostoru od Atlantika do Avganistana postoji specifičan oblik bezbednosne međuzavisnosti.

Promena unutrašnjih granica regionalnog bezbednosnog kompleksa Bliskog istoka

Transformacija unutrašnjih granica $u$ regionalnom bezbednosnom kompleksu vezuje se za promene $u$ obrascima sekuritizacije i njihova je posledica. U tom smislu, one (granice) su relativna kategorija, i već sa samom promenom vlasti u jednoj zemlji može doći do promene granica između potkompleksa.

$S$ obzirom na značajne promene $u$ obrascima prijateljstava $i$ neprijateljstava $u$ Bliskoistočnom RBK, čini se da se granica između Zalivskog i Levantskog potkompleksa može obrisati. Najpre, sukob 
Saudijske Arabije i Irana, jedan od najdominantnijih obrazaca sekuritizacije na prostoru Zaliva, prelio se i na prostor Levanta, gde su se u Siriji dve zemlje indirektno borile za prevlast, odnosno suzbijanje uticaja druge strane. Drugi značajan obrazac sekuritizacije je sukob Izraela i Irana, koji je sada bezmalo jedan od najznačajnijih odnosa sa potencijalnim implikacijama na bezbednost čitavog Bliskog istoka. Ne samo da se Izrael bori da izbaci Iran iz Sirije i Libana, već dve zemlje u kontinuitetu prete jedna drugoj ratnim razaranjima na suparnikovoj teritoriji. Bezbednosne interakcije između Izraela i Irana su danas većeg intenziteta nego one između Izraela i Jordana; da ne govorimo o Egiptu, koji je, zabrinut za održanje vladajućeg režima, više zagledan na zapad nego na severoistok. U tom smislu, i samo članstvo Egipta u Levantskom potkompleksu deluje kao problematično, tim pre što je ono bilo diktirano geografskom blizinom Izraelu i zaokupiranošću palestinskim pitanjem. Danas, kada je Egipat više zainteresovan za ishod građanskog rata u Libiji nego za ishod izraelskopalestinskog sukoba, malo je osnova za svrstavanje Egipta $u$ isti koš sa državama poput Sirije. Naposletku, ostaje prostora za diskusiju o statusu potkompleksa Magreba unutar šireg, Bliskoistočnog regionalnog bezbednosnog kompleksa. Buzan i Vejver su i sami Magreb okarakterisali kao (pot)kompleks (sa zagradom), dajući jasnu aluziju na niži stepen zavisnosti ovog prostora $\mathrm{u}$ odnosnu na bezbednosna pitanja koja dominiraju istočnim delom kompleksa i mogućnost da i sam jednog dana možda preraste $u$ regionalni bezbednosni kompleks. Ipak, vreme je potvrdilo njegov status potkompleksa, upravo zbog arabizma, islama i deljenja zabrinutosti zbog islamističke opozicije sa najvećim brojem država iz istočnog dela kompleksa. Uprkos slabljenju vezivne uloge koju izraelskopalestinski sukob ima za celovitost Bliskoistočnog RBK, ,Arapsko proleće“ je potvrdilo visok stepen bezbednosne međuzavisnosti Magreba i Mašreka koju su prepoznala ova dvojica autora.

\section{SPOLJAŠNJA TRANSFORMACIJA REGIONALNOG BEZBEDNOSNOG KOMPLEKSA BLISKOG ISTOKA}

Spoljašnja transformacija RBK događa se promenom njegovog sastava, bilo da se radi o ulasku novih članova, izlasku postojećih, podeli ili spajanju sa drugim kompleksom. Poslednjih dvadeset godina, kao najozbiljniji kandidat za ulazak u Bliskoistočni RBK nametnula se Turska, koja je od 
strane Buzana i Vejvera prepoznata kao izolator koji razdvaja bezbednosne dinamike tri okolna kompleksa. Budući da su izolatori uvek potencijalni kandidati za spoljašnju transformaciju RBK (Buzan and Wæver 2003, 487), njihove pozicije su itekako podložne uticaju protoka vremana, naročito ako se radi o aktivnom i ambicioznom izolatoru kakav je Turska. Ni dvadeset godina nakon definitivnog formulisanja teorije, njene izolacione sposobnosti se ne mogu zanemariti, iako su itekako stavljene pred izazov „Arapskim prolećem“ i migrantskom krizom koja je ubrzo usledila. Ankara je uspela da stavi migrantsku krizu pod kontrolu, za šta je diplomatskim kanalima izdejstvovala obilatu finansijsku pomoć od EU (Janković 2016a). Nadgornjavanje oko izbeglica, mahom sa prostora Sirije, dovoljno govori o nameri Turske da naplati svoju ulogu izolatora, odnosno o spremnosti EU da Turskoj plati za obavljanje te funkcije. Povremene pretnje da će se pustiti da kriza izmakne kontroli, ipak govore da izolacija bezbednosne dinamike nije datost koja je rezultat samo određenih geopolitičkih okolnosti, već da u velikoj meri zavisi od agende vladajuće strukture u državi izolatoru.

Uloga Turske kao izolatora nije dovedena u pitanje samo prelivanjem bezbednosnih izazova iz jednog kompleksa u drugi, kakva bi svakako bila upotreba migranata $u$ svrhu pritiska na EU čije su pojedine članice sekuritizovale migrantsko pitanje kao pretnju sopstvenoj društvenoj stabilnosti. Povod za preispitivanje te uloge može se naći i u njenoj sve većoj uključenosti $u$ bezbednosnu dinamiku Bliskoističnog RBK. Namera Erdogana i njegove partije AK da Tursku pozicioniraju kao lidera $u$ islamskom svetu dobro je poznata. Međutim, u poslednjih deset godina Turska je intenzivirala svoje bezbednosno prisustvo na Bliskom istoku do mere da je važniji činilac regionalne bezbednosne dinamike nego mnoge članice Bliskoistočnog RBK.

Upadi turskih snaga na sever Sirije i Iraka kako bi se obračunala sa Radničkom partijom Kurdistana datiraju još od devedesetih godina (Jojić, 2018), ali stepen njene umešanosti danas daleko prevazilazi ranije ograničene intervencije. Turska je od početka građanskog rata u Siriji pokrenula tri velike vojne operacije protiv Kurda, koje za rezultat imaju okupaciju delova severa zemlje. Na taj način, ona je uspela da se izbori za ulogu nezaobilaznog faktora u nastojanjima da se diplomatskim ili vojnim putem dođe do okončanja sukoba. Negativan odnos prema političkoj autonomiji Kurda u svom okruženju nosi sa sobom potencijal da trajno veže Tursku za bezbednosna pitanja severnih krajeva Bliskog istoka. Ankara je, 
uz Iran, glavni zagovornik prava Palestinaca, često se zalažući za stvaranje širokog fronta islamskih zemalja za politički obračun sa Izraelom. Ona je, takođe, aktivni učesnik rata u Libiji, gde pruža podršku islamističkoj vladi $\mathrm{u}$ Tripoliju, kao i jedan od glavnih učesnika nadmetanja oko energenata $\mathrm{u}$ istočnom Mediteranu, sa više nego očiglednim bezbednosnim implikacijama. Takođe, Turska je uzela aktivno učešće u sukobu Saudijske Arabija i Katara, gde je čak stacionirala i deo oružanih snaga, s ciljem pružanja podrške Kataru u tom političkom sukobu.

Turska je, dakle, poslednju deceniju najdirektnije vezana za bezbednosnu dinamiku istočnog potkompleksa. Široka lepeza aktivnosti sa očiglednim posledicama na bezbednost regije govori u prilog tome, a ambicije aktuelne vladajuće garniture u Ankari sugerišu da će tako biti i u budućnosti. ${ }^{3}$ Regionalnoj sili je potreban region, a Bliski istok se nameće kao prirodan izbor, tim pre što Erdoganova partija ima jasne ambicije da Tursku pozicionira kao lidera islamskog sveta. Centralna Azija je daleko, a Rusija je u nedavnom ratu između Jermenije i Azerbejdžana potvrdila dominaciju na prostoru Kavkaza. Ujedno, sve većim udaljavanjem od Evropske unije tokom protekle decenije, Turska se postepeno isključuje iz evropske bezbednosne dinamike, ukoliko izuzmemo nadgornjavanje sa Grčkom u Egeju, koje će najverovatnije ostati samo na retorici. Čak i kada je povremeno izbijala u prvi plan evropske bezbednosne agende, kao u slučaju migrantske krize, to je bilo iznuđeno turskom geografskom blizinom Bliskom istoku. Kako je njena vezanost za Bliskoistočni RBK više trajnog karaktera, Turska bi se danas pre mogla odrediti kao član kompleksa koji vrši određene izolacione funkcije, nego kao aktivni izolator koji često penetrira $\mathrm{u}$ regionalnu bezbednosnu dinamiku. Njeno članstvo povlači sa sobom i posledice po ostale elemente esencijalne strukture RBK Bliskog istoka raspodelu moći, unutrašnje granice i obrasce prijateljstava i neprijateljstava.

\section{ZAKLJUČAK}

Tokom poslednjih dvadeset godina na Bliskom istoku došlo je do značajnih događaja, koji su ostavili posledice na esencijalnu strukturu tamošnjeg regionalnog bezbednosnog kompleksa. Najvažniji među njima

\footnotetext{
${ }^{3}$ Više o regionalnim i globalnim ambicijama savremene Turske videti u: Janković $2016 \mathrm{~b}$.
} 
je „Arapsko proleće“ i serija unutrašnjih promena koje su potresale države Bliskog istoka, sa značajnim regionalnim implikacijama. Vezana sopstvenim ambicijama i fokusom na kurdsko pitanje Turska je danas ravnopravni član RBK, što je proizvelo posledice i po ostale elemente esencijalne strukture. Ova vrsta spoljašnje transformacije RBK dovela je i do promene u raspodeli moći unutar samog kompleksa, pa je Turska danas uz Saudijsku Arabiju, Izreal i Iran, jedan od četiri dominantna pola unutar novoformiranog istočnog potkompleksa. Do promena u polaritetu unutar potkompleksa, ali i u okviru šireg Bliskoistočnog regionalnog bezbednosnog kompleksa, došlo je i urušavanjem velikog broja država. Kao najdrastičniji primeri u opadanju moći mogu se uzeti Sirija, Irak, Libija i Jemen. Sa druge strane, tokom poslednje dve decenije došlo je do značajne akumulacije moći od strane monarhija iz Persijskog zaliva, u prvom redu Saudijske Arabije. Značajni uzroci transformacije kompleksa mogu se naći i u promenama obrazaca prijateljstava i neprijateljstava. Novi član, Turska, danas je uz Iran, palestinske organizacije i Hezbolah nosilac antiizraelske osovine na Bliskom istoku. Privrženost ovom obrascu sekuritizacije slabi u slučaju drugih islamskih zemalja, nekada nosilaca anticionističke histerije u regionu. Egipat je danas više zagledan ka zapadu, dok je Saudijska Arabija fokusirana na sukob sa Iranom, koji je i samu gura bliže Izraelu i Sjedinjenim Državama. Novi obrasci diktiraju i promenu unutrašnjih granica kompleksa, koji se danas može podeliti na dva potkompleksa - Zapadni i Istočni. Zapadni, ili afrički potkompleks, obuhvata države Magreba i Egipat, dok se Istočni, azijski potkompleks, sastoji od država nekadašnjeg Levantskog i Zalivskog kompleksa, sa izuzetkom Egipta i uz prisustvo novog člana - Turske. "Arapsko proleće“ je potvrdilo značaj arabizma i islama kao vezivnog faktora za regionalnu bezbednosnu dinamiku Bliskoistočnog RBK, pa se uprkos slabljenju značaja izraelsko-palestinskog sukoba i dalje može govoriti o jedinstvenom regionalnom bezbednosnom kompleksu Bliskog istoka. Sama dinamičnost političko-bezbednosnih događanja i permanentna tranzicija u kojoj se Bliski istok nalazi, međutim, ostavljaju veliki prostor za dalje promene $\mathrm{u}$ budućnosti. 


\section{BIBLIOGRAFIJA}

Aarts, Paul. 1999. "The Middle East: a region without regionalism or the end of exceptionalism?". Third World Quarterly 20 (5): 911-925.

Alsaafin, Linah. 2020. "How did Israel and the UAE get to normalizing relations?", AlJazeera, 14 August. https://www.aljazeera.com/news/ 2020/8/14/how-did-israel-and-the-uae-get-to-normalising-relations

Axworthy, Michael. 2017. “Islam's great schism”, New Statesman, August 29.

Bahgat, Gawdat and Anoushiravan Ehteshami. 2017. "Iran's Defense Strategy: The Navy, Balistic Missles and Cyberspace". Middle East Policy 24 (3): 89-103.

Beck, Martin. 2019. Israel and the Arab Gulf: An Israel-Saudi Alliance in the Making. Odense: SDU's Resource Center on Middle East Studies.

Beck, Martin. 2020. “The Aggravated Struggle for Regional Power in the Middle East: American Allies Saudi Arabia and Israel versus Iran". Global Policy 11 (1): 84-92.

Blanga, Yehuda U. 2017. "Saudi Arabia's Motives in the Syrian Civil War". Middle East Policy 24 (4): 45-62.

Buzan, Barry. 1983. "Regional Security as a Policy Objective: The Case of South and Southwest Asia". In: The Great Game: The Rivalry in the Persian Gulf and South Asia, edited by Alvin Z. Rubinstein, 261-278. New York: Praeger.

Buzan, Barry. 1991. People, States and Fear: An Agenda for International Security Studies in the post-Cold War Era. Colorado: Lynee Rienner Publishers.

Buzan, Barry and Ole Wæver. 2003. Regions and Powers: The Structure of International Security. New York: Cambridge University Press.

Fitzpatrick, Mark. 2011. Nuclear capabilities in the Middle East. Brussels: EU Non-Proliferation Consortium.

Hassan-Yari, Houchang. 2016. "Middle East Warfighting Capabilities in 2025". In: The Future of Regional Security in the Middle East: Expert Perspectives on Coming Developments, edited by Erika Holmquist and John Rydqvist, 100-108. Stockholm: FOI.

Holmes, Oliver. 2020. "Netanyahu hold secret meeting with Saudi crown prince", The Guardian, 23 November. https:/ / www.theguardian.com/ world/2020/nov/23/ benjamin-netanyahu-secret-meeting-saudicrown-prince-mohammed-bin-salman 
Janković, Slobodan. 2016a. „Izbegličko-migrantska kriza: uzrok, posledice i smisao". Nacionalni interes 25 (1): 69-102.

Janković, Slobodan. 2016b. "Vectors of Turkish foreign policy: What remains of the strategy for 2023?". Medunarodni Problemi 68 (1): 7-23.

Janković, Slobodan. 2020. "The South and East Mediterranean power struggle: cases of Libya and Syria". The Review of International Affairs 71 (1178): 79-97.

Jojić, Stefan. 2018. “Turkey's Kurdish Conflict: Genesis and a Political Context". The Review of International Affairs 69 (1171): 49-63.

Jojić, Stefan. 2019. „Mesto Persijskog zaliva u spoljnoj politici Donalda Trampa“. U: Kontroverze spoljne politike SAD i medunarodnih odnosa u Trampovoj eri, uredili Vladimir Trapara i Aleksandar Jazić, 178-198. Beograd: Institut za međunarodnu politiku i privredu.

Kizilkaya, Yafer. 2017. “Hiybullah's Moral Justification of Its Military Intervention in the Syrian Civil war". The Middle East Journal 71 (2): 211 228.

Koch, Christian. 2019. The Evolution of the Regional Security Complex in the MENA Region. Abu Dhabi: Emirates Diplomatic Academy.

Laub, Zachary. 2018. "The Islamic State", Council on Foreign Relations, August 10. https:// www.cfr.org/backgrounder/islamic-state

Lister, Charles. 2014. Profiling the Islamic State. Doha: Brookings Doha Center.

Mabon, Simon. 2012. “The Battle for Bahrain: Iranian-Saudi Rivalry”. Middle East Policy 19 (2): 84-97.

Oktav, Ozden Zaynep. 2011. "The Gulf States and Iran: A Turkish Perspective". Middle East Policy 18 (2): 136-147.

Rezaei, Ferhad. 2017. "Sanctions and Nuclear Rollback: The Case of Iran". Middle East Policy 24 (2): 74-90.

Santini, Ruth H. 2017. "A New Regional Cold War in the Middle East and North Africa: Regional Security Complex Theorz Revisited". The International Spectator 52 (4): 93-111.

Saouli, Adham. 2016. "Armaed Political Movements in the Middle East". In: The Future of Regional Security in the Middle East: Expert Perspectives on Coming Developments, edited by Erika Holmquist and John Rydqvist, 90-99. Stockholm: FOI. 
[SIPRI] Stockholm International Peace Research Institute. 2020. "Sipri Military Expenditure Database". Accessed 29 April 2021. https://www.sipri.org/databases/milex

Sullivan, Paul. 2016. "Energy, Politics, and Security in the Middle East and North Africa". In: The Future of Regional Security in the Middle East: Expert Perspectives on Coming Developments, edited by Erika Holmquist and John Rydquist, 68-77. Stockholm: FOI.

Taha, Rawad. 2021. "Iran parliament discusses bill to 'eleminate Israel by March 2041", Al Arabiya, 4 January. https://english.alarabiya.net/ News/middle-east/2021/01/04/Iran-parliament-discusses-bill-toeliminate-Israel-by-March-2041-

Tasnim News Agency. 2017. "Iran's Defense Minister Warns Saudis of Harsh Reaction" 8 May. https://www.tasnimnews.com/en/news/2017/ 05/08/1400962/iran-s-defense-minister-warns-saudis-of-harshreaction

Wright, Robin and Peter Beker. 2004. "Iraq, Joran See Threat to Election From Iran", The Washington Post, 8 December. https://www. washingtonpost.com/archive/politics/2004/12/08/iraq-jordan-seethreat-to-election-from-iran/7e0cc1bc-aeb3-447a-bc9e-cfa5499699bc/

Wezeman, Pieter D. 2011. Conventional strategic military capabilities in the Middle East. Brussels: EU Non-Proliferation Consortium.

Wezeman, Pieter D. and Alexandra Kuimova. 2019. Military Spending and Arms Imports by Iran, Saudi Arabia, Qatar and the UAE. Solna: SIPRI.

\section{THE MIDDLE EAST REGIONAL SECURITY COMPLEX}

Abstract: With an emphasis on the regional level of analysis and the key impact of regional interactions on security outcomes, the Theory of Regional Security Complex provides an original standing point for studying many of the issues that burden contemporary international political reality. In order to cope with the challenges posed by time flow and the extraordinary dynamics of international security, it is necessary to harmonize its theoretical settings and apparatus according to impulses from empiricism. One of the most dynamic regions of the world in terms of security is the Middle East, where wars, changes in the distribution of 
power, and specific security challenges over the past two decades have influenced the change in the security configuration of the region. More specifically, there have been minor or major changes in all elements of the essential structure of the regional security complex. Their detection and explanation are the aims of this article. The emergence of new and the disappearance of once key factors in regional security dynamics, as well as the political realignments in the Middle East, signal changes in the patterns of amity and enmity and the power distribution in the region. Although most of the old patterns are retained, there is a change in some of them and the creation of new ones. On the other hand, the balance of power has been disrupted by the emergence of non-state actors, the disappearance of old ones, and the strengthening of new power poles on the security map of the Middle East. Some of the traditional patterns of enmity, such as the Saudi-Israeli one, have fallen into the background, receding in the face of the pragmatic need of former enemies to confront Iran. The distribution of power has also changed with the active inclusion of insulators in regional security dynamics, where Turkey is emerging as an actor that has decisively interfered in some of the burning issues of regional conventional and energy security over the past decade. Turkey's specific role in the Middle East RSC imposes the need to reconsider the role of insulators. Finally, as a consequence of changes in the previous factors of the essential structure, there have been significant changes in the boundaries of the regional security complex itself. Turkey's specific role in recent years has led to a change in external borders through its direct involvement in the security dynamics of the Middle East. Also, although factors that bind security dynamics over a wide area from the Atlantic to Afganistan are still present, specific subregional dynamics have led to changes in the internal boundaries of the complex, merging and reconfiguring the subcomplexes.

Keywords: regional security complex, the Middle East, the War in Syria, Turkey, Iran. 